Article

\title{
Estimation of Agricultural Dykelands Cultivated in Nova Scotia Using Land Property Boundaries and Crop Inventory
}

\author{
Mathieu F. Bilodeau ${ }^{1}{ }^{(}$, Travis J. Esau ${ }^{1, * \mathbb{C}}$, Aitazaz A. Farooque ${ }^{2}$, Qamar U. Zaman ${ }^{1}$ and Brandon Heung ${ }^{3}$ \\ 1 Department of Engineering, Faculty of Agriculture, Dalhousie University, Truro, NS B2N 5E3, Canada; \\ Mathieu.Bilodeau@dal.ca (M.F.B.); qzaman@dal.ca (Q.U.Z.) \\ 2 School of Sustainable Design Engineering, University of Prince Edward Island, \\ Charlottetown, PE C1A 4P3, Canada; afarooque@upei.ca \\ 3 Department of Plant, Food, and Environmental Sciences, Faculty of Agriculture, Dalhousie University, \\ Truro, NS B2N 5E3, Canada; brandon.heung@dal.ca \\ * Correspondence: tesau@dal.ca
}

Citation: Bilodeau, M.F.; Esau, T.J.; Farooque, A.A.; Zaman, Q.U.; Heung, B. Estimation of Agricultural Dykelands Cultivated in Nova Scotia Using Land Property Boundaries and Crop Inventory. ISPRS Int. J. Geo-Inf. 2021, 10, 801. https://doi.org/ 10.3390/ijgi10120801

Academic Editor: Wolfgang Kainz

Received: 27 August 2021

Accepted: 28 November 2021

Published: 30 November 2021

Publisher's Note: MDPI stays neutral with regard to jurisdictional claims in published maps and institutional affiliations.

Copyright: (c) 2021 by the authors. Licensee MDPI, Basel, Switzerland. This article is an open access article distributed under the terms and conditions of the Creative Commons Attribution (CC BY) license (https:// creativecommons.org/licenses/by/ $4.0 /)$.

\begin{abstract}
Dykelands are agricultural ground protected from coastal inundation by dyke infrastructure and constitute some of the most agriculturally productive lands in Nova Scotia. Between 2015 and 2019, Canada's Annual Crop Inventory was used to characterize and estimate hectares of agricultural dykelands cultivated in Nova Scotia. The number of hectares of wheat, barley, corn, forages and soybeans were compiled for each year and compared to the previous year. This was accomplished using GIS software, satellite images, and geodata from the Nova Scotia's Land Property Database. Results revealed that from 2015 to 2019, an average of $56 \%$ of the dykelands' total surface was dedicated to the production of field crops (wheat, barley, corn, soybeans) and forage. Results also highlighted the importance of forage production on the dykelands. Forage was the largest commodity grown, representing around $80 \%$ of the total crop land area of the agricultural dykelands. Corn and soybeans were the second and third crops of abundance, constituting 12 and $4 \%$ of the total crop land area, respectively. This study represents the first attempt to document the number of hectares of the principal crops grown on Nova Scotia's dykelands using crop inventory and property boundaries. Given the predictions of rising sea levels and the overtopping risks that the dykelands face, this study will facilitate more suitable land-use policies by providing stakeholders with an accurate quantitative assessment of the utilization of agricultural dykelands.
\end{abstract}

Keywords: land cover; land use; remote sensing; GIS; crop inventory; dykelands; agriculture; Nova Scotia

\section{Introduction}

Dykelands are agricultural lands protected from coastal inundation via dyke infrastructure and constitute some of the most agriculturally productive lands in NS, Canada. Agricultural dykelands are used mainly to produce hay and pasture, corn, and cereal crops [1]; however, many other crops have historically been found to be agriculturally viable on the dykelands, such as root crops, soybeans, chives, sunflowers, salad greens, and cabbage [2]. Other sources also reported that on well-drained dykelands, beans, beets, swedes, carrots, spinach, and celery had been successfully grown on these soils [3]. It is estimated that 17,401 hectares of tidal land are being protected by the Nova Scotia Department of Agriculture (NSDA), which represents approximately 10\% of Nova Scotia's active agricultural land [4,5].

In 1954, Baird [3] estimated the total area of dykelands in the Maritime Provinces ranged between 28,300 to 32,300 hectares and suggested that another 6000 to 8000 hectares could be reclaimed by the construction of mud dykes. He also noted that out of this number, approximately 4000 to 6000 hectares had a different soil texture from the average dykelands soils and could be made very productive when properly drained and cultivated [3]. 
In 1939, the Maritime Beef Cattle Committee funded a study on the dykelands to understand the challenges that the dykeland owners of the Chignecto Isthmus area $\left(45.8482^{\circ} \mathrm{N}\right.$, $64.2881^{\circ} \mathrm{W}$ ) were facing. As a results from this study, twelve elements were highlighted to be of vital interest to dykelands owners at the time. These recommendations can be summarized into two important themes: the importance of maintaining and improving dyke infrastructure and associated drainage systems; and improving hay production on grazing lands [3]. These recommendations shaped long-term land management practices and are still prevalent to this day through the adoption of recent federal and provincial government policies [6]. Today, dykelands still play an important role in Nova Scotia since they hold a diversity of public and private assets and infrastructures, such as roads, malls, suburbs, and sewage treatment plants [7].

A report on agricultural dykelands published in 2013 suggested that the importance of dykelands in the province is attributable to the large production of forage on this land, estimated at $24.8 \%$ of the province's overall forage production $[2,8]$. Other reports estimated that roughly $15 \%$ of marshlands ( 2610 hectares) are not being farmed in Nova Scotia and are used for non-agricultural practices and development [9]. To date, these estimates remain vague and do not provide a clear characterization of the state of agricultural situation on the dykelands.

This is especially pertinent in the context of current and future climate change [10-12]. This situation was outlined in a study by van Proosdij and Page [13], which predicted a relative sea-level rise in Nova Scotia, ranging from 70 to $140 \mathrm{~cm}$ over the next century and will therefore increase the vulnerability of the dyke system to storm surges [13]. Within the next 50 years, approximately $70 \%$ of the $241 \mathrm{~km}$ of dykes in the province could be at high risk of coastal erosion and overtopping [14].

Today, dykeland stakeholders are seeking to understand in which scenario underutilized dykelands should be maintained, converted to agricultural use, or restored into salt marshes. Knowing when and how to manage these scenarios is especially pertinent, considering that most of these dyke infrastructures will have to be maintained in the coming years due to rising sea levels. Unfortunately, very little information on what is being grown and how many hectares of crops are being grown are currently available for dykelands [10-12]. Given the predictions of rising sea levels, challenges regarding a proper assessment of the resources of the dykelands must be addressed. To develop suitable land-use policies, there must be an accurate quantitative assessment of the land utilization of dykelands.

To address the challenges associated with quantifying land use in dykelands, remote sensing techniques may be leveraged. The rich literature related to land-cover mapping can be mainly categorised into satellite-based techniques and survey-based methodology. Satellite-based techniques of land-cover mapping involves the interpretation of remotely sensed data generally derived from satellite images [15]. Early efforts of land cover mapping used either a coarse resolution sensor and focused on the characterization land cover for a single point in time (e.g., Loveland et al. [16]), or used moderate resolution imagery for single class mapping $[17,18]$.

\section{Related Work}

One of the first coarse-resolution, global land cover databases used in global environmental studies included the Matthews et al. and Wilson and Henderson-Sellers [19-21] global databases [15]. In the early 21st century, Loveland et al. [15] developed a global land cover database with $1 \mathrm{~km}$ spatial resolution using Advanced Very High-Resolution Radiometer (AVHRR) data. This global database consisted of numerous seasonal land cover regions that could be used in global environmental studies.

At present, few studies have used a combination of property boundaries and crop inventory for agriculture analysis. Previous research focused mainly on land-cover mapping or the development of automated process to delineate farm fields [16,22]. Related work by McCracken et al. [23] used 400 property boundaries in the Brazilian Amazon 
to identify land-cover class patterns that reflect farming differences. Results from the study demonstrated that the use of remote sensing and GIS techniques integrated with information from property boundaries helped explain deforestation at a very small scale.

Other similar work from Hanus et al. [24] investigated the accuracy of cadastral parcel boundaries with GIS. Results showed that a good understanding of the accuracy of cadastral data could contribute to regional development. Precise measurement of parcel boundaries guarantees stability for farmers who collect subsidies for agricultural and forestry parcels from EU funds.

In recent years, the improvement capability of satellite sensors (e.g., Landsat 8, Worldview-3, and PlanetScope) allowed a more precise crop inventory and at higher spatial resolutions. In Meyer et al. [25], they investigated the possibility of accurately splitting large areas of land into discrete fields using high-resolution satellite images as well as deep learning algorithms. Similarly, North et al. [22] developed an automated method of deriving closed polygons around fields from time-series satellite imagery. This technique was proven to be successful in mapping large agricultural study sites $\left(4000 \mathrm{~km}^{2}\right)$ and for segmenting parcels of land containing different crops and pasture [22].

The use of statistical surveys and census approaches to quantify land change contributes valuable information to our understanding of crop change but does not offer a comprehensive assessment at smaller scales. Data is often difficult to acquire and inconsistent due to the spatial and temporal complexity that are not adequately captured in national agricultural census [18]. In Canada, crop insurance data have historically been the most precise and comprehensive sources of information for crop type information [26]. Unfortunately, this data, which is provided by crop insurance agencies, can only be accessed in Alberta, Saskatchewan, and Quebec [26]. Additionally, Statistics Canada stopped collecting survey-based information on land use in 2011, and started to use annual crop inventories derived from satellite imagery [26,27].

Previous works that estimated dykelands in the province were conducted at a smaller scale, which often resulted in fragmented information on cropping potential $[3,4,9]$. The use of satellite images and GIS allows decision-makers to have a more precise understanding of the agricultural potential on the dykelands. Due to the lack of a comprehensive crop inventory of the dykelands, the objective of this study is to increase the understanding of the land allocation of corn (Zea mays L), barley (Hordeum vulgar L.e), soybeans (Glycine max L.), wheat (Triticum aestivum L.) and forages on the dykelands of Nova Scotia. This will be accomplished by estimating the total number of hectares of cropland produced from 2015 to 2019. The goal of this paper is to document the number of hectares of the principal crops grown on Nova Scotia's dykelands using crop inventory and property boundaries data. Results of this paper are divided into three parts. First, results from the Annual Crop Inventory analysis for the dykelands were compiled from 2015 to 2019. Second, a five-year average analysis of crops produced on the dykelands was accomplished to define the most abundant crop. Third, the analysis was broken down by county to understand better the most productive region for field crops and forage.

\section{Materials and Methods}

\subsection{Study Area}

Although predominantly agricultural lands, dykelands have also been used historically for several other applications. The dykelands system in Nova Scotia protects over 600 residential and commercial buildings, $25 \mathrm{~km}$ of railway, $80 \mathrm{~km}$ of paved roads and trails, and more than $120 \mathrm{~km}$ of power lines from storm surges and floods [1,28]. The major dyke systems in Nova Scotia are located in four main regions (Figure 1): Cumberland, Colchester, Hants and Kings, and Annapolis and Digby [14]. These regions are Nova Scotia's agricultural heartland, surpassing all other counties in terms of the number of farms and the total crop area [5]. 


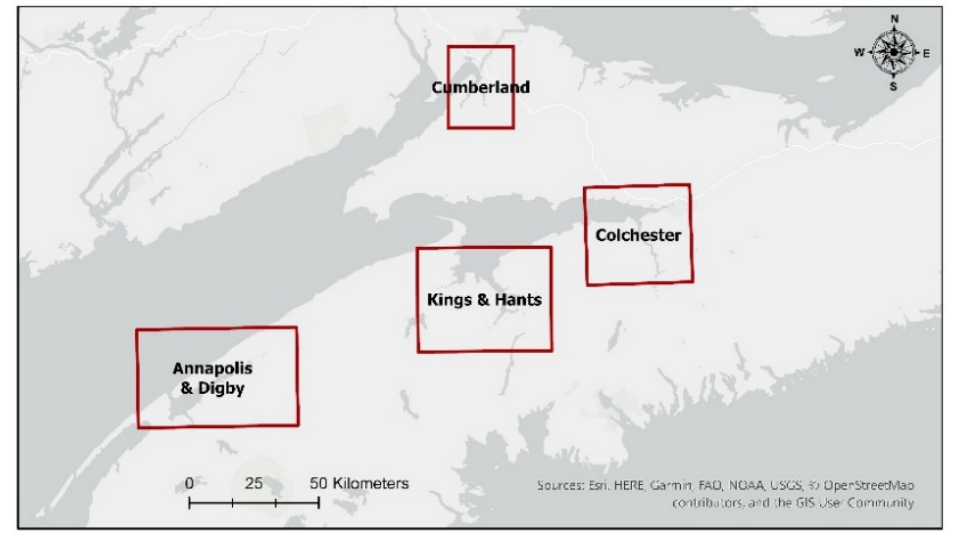

Figure 1. Geographical distribution of analysis regions based on the provincial distribution of dykelands (adapted from van Proosdij et al. [14]).

\subsection{Datasets}

\subsubsection{Annual Crop Inventory}

The Agriculture and Agri-Food Canada (AAFC) Annual Crop Inventory from 2015 to 2019 was used as a primary source of data. The annual inventory is published by the Earth Observation Team of the Science and Technology Branch (STB) at AAFC. The digital maps were created using optical (Landsat-8, Sentinel-2) and radar (RADARSAT-2) based satellite images using a decision tree classifier [26]. The Annual Crop Inventory maps are useful in understanding the state and trends of agricultural production at a high spatial resolution (30 m) (Figure 2).

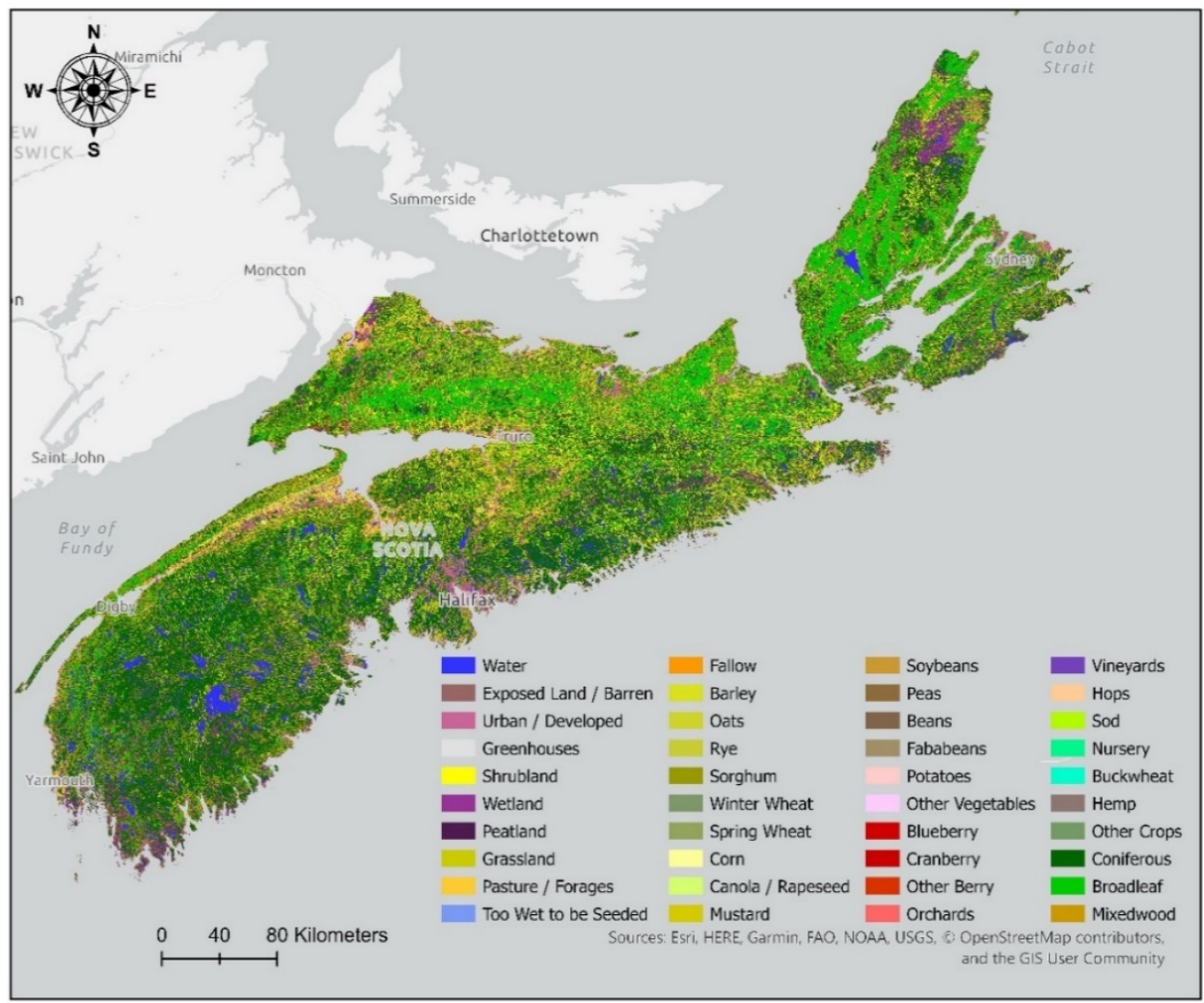

Figure 2. Agriculture and Agri-Food Canada Crop Inventory Map of Nova Scotia in 2019.

To validate the satellite data analysis, AAFC acquired ground-truth information as point observations as well as data from other provincial sources. For each year, tens of thousands of points that identified crops across Canada were combined and used as 
training or reference sites [26]. However, the classification accuracy is not uniform and tends to vary annually and provincially. The differences in accuracy were related to the differences in the satellite data availability and the distribution of training site for each province [26]. Table 1 shows the overall accuracies of the Annual Crop Inventory in Nova Scotia used in this analysis.

Table 1. Overall accuracies of the Annual Crop Inventory in Nova Scotia (adapted from Agriculture and Agri-Food Canada [29]).

\begin{tabular}{cc}
\hline Overall Accuracies of the Annual Crop Inventory \\
\hline 2015 & $85.2 \%$ \\
2016 & $90.6 \%$ \\
2017 & $89.5 \%$ \\
2018 & $92.5 \%$ \\
2019 & $89.1 \%$ \\
\hline
\end{tabular}

\subsubsection{Property Boundaries}

The Nova Scotia property boundaries from the Nova Scotia Property Records Database (NSPRD) were used to segment the data from the crop inventories and attribute the crop types to the property polygons. To date, this dataset provides the most reliable GIS information on each property of the province. Information such as land use, contained in the NSPRD, was useful in filtering the data and eliminate outliers. The property boundaries used for this analysis were updated in April 2019.

\subsubsection{Marsh Boundaries}

The boundaries of the dykelands were provided by the NSDA in a shapefile format. This dataset was digitized from the 1950's and 1960's Agricultural Marsh Plans of Works and compiled in the 1990's. The boundaries refer to the legislated agricultural marshland defined under the Agricultural Marshland Conservation Act. This dataset was used to identify which fields were parts of the dyke system and which were not.

\subsubsection{Satellites Images}

The PlanetScope satellite (Planet Labs Inc., San Francisco, CA, USA) takes images of Earth's land surface daily at a $3 \mathrm{~m}$ spatial resolution [30]. These images were used to resolve ambiguity in the land usage associated with the property boundaries. More specifically, it was useful to remove roads, forested areas, and bodies of water features from the datasets. A series of satellite images were selected between June and August from 2016 to 2019 (Table 2).

Table 2. List of Planet satellite images used in the study.

\begin{tabular}{ccccc}
\hline Source & Dates & Day of Year & Time & Spatial Resolution (m) \\
\hline 4-band PlanetScope Scene & 1 July 2016 & 183 & $12: 12$ & 3.2 \\
4-band PlanetScope Scene & 1 July 2016 & 183 & $12: 15$ & 3.2 \\
4-band PlanetScope Scene & 23 August 2016 & 229 & $12: 40$ & 2.5 \\
4-band PlanetScope Scene & 26 June 2017 & 177 & $17: 28$ & 3.1 \\
RapidEye Ortho Tile & 6 July 2017 & 187 & $15: 33$ & 6.5 \\
4-band PlanetScope Scene & 29 August 2017 & 241 & $15: 09$ & 3.7 \\
4-band PlanetScope Scene & 30 June 2018 & 131 & $14: 41$ & 3.8 \\
4-band PlanetScope Scene & 7 August 2018 & 219 & $14: 40$ & 3.7 \\
4-band PlanetScope Scene & 28 August 2018 & 240 & $14: 41$ & 3.9 \\
4-band PlanetScope Scene & 8 July 2019 & 189 & $14: 58$ & 4.0 \\
4-band PlanetScope Scene & 16 July 2019 & 197 & $14: 46$ & 3.9 \\
4-band PlanetScope Scene & 28 July 2019 & 209 & $13: 26$ & 3.5 \\
4-band PlanetScope Scene & 15 August 2019 & 227 & 240 & 3.9 \\
4-band PlanetScope Scene & 28 August 2019 & & \\
\hline
\end{tabular}




\subsection{Data Processing}

To assign a land use to the property boundaries, the Annual Crop Inventory raster layers were clipped to the edges of the marsh bodies. Here, the zonal statistics tool within ArcGIS Pro (ESRI, Redlands, CA, USA) was used to identify the dominant crop type from the crop inventory within each property boundary polygon (Figure 3). This approach allowed each property unit within the NSPRD to be assigned a crop type within the marsh bodies, thus enabling the possibility of estimating the number of hectares of crops produced each year. All of the fields that were not assigned a class were removed from the database. Additionally, all the water, road, and rail polygon segments were selected and removed from the dataset. The filtering process provided a stronger characterization of the crops grown on the dykelands by eliminating non-agricultural fields that could compromise the rest of the analysis.

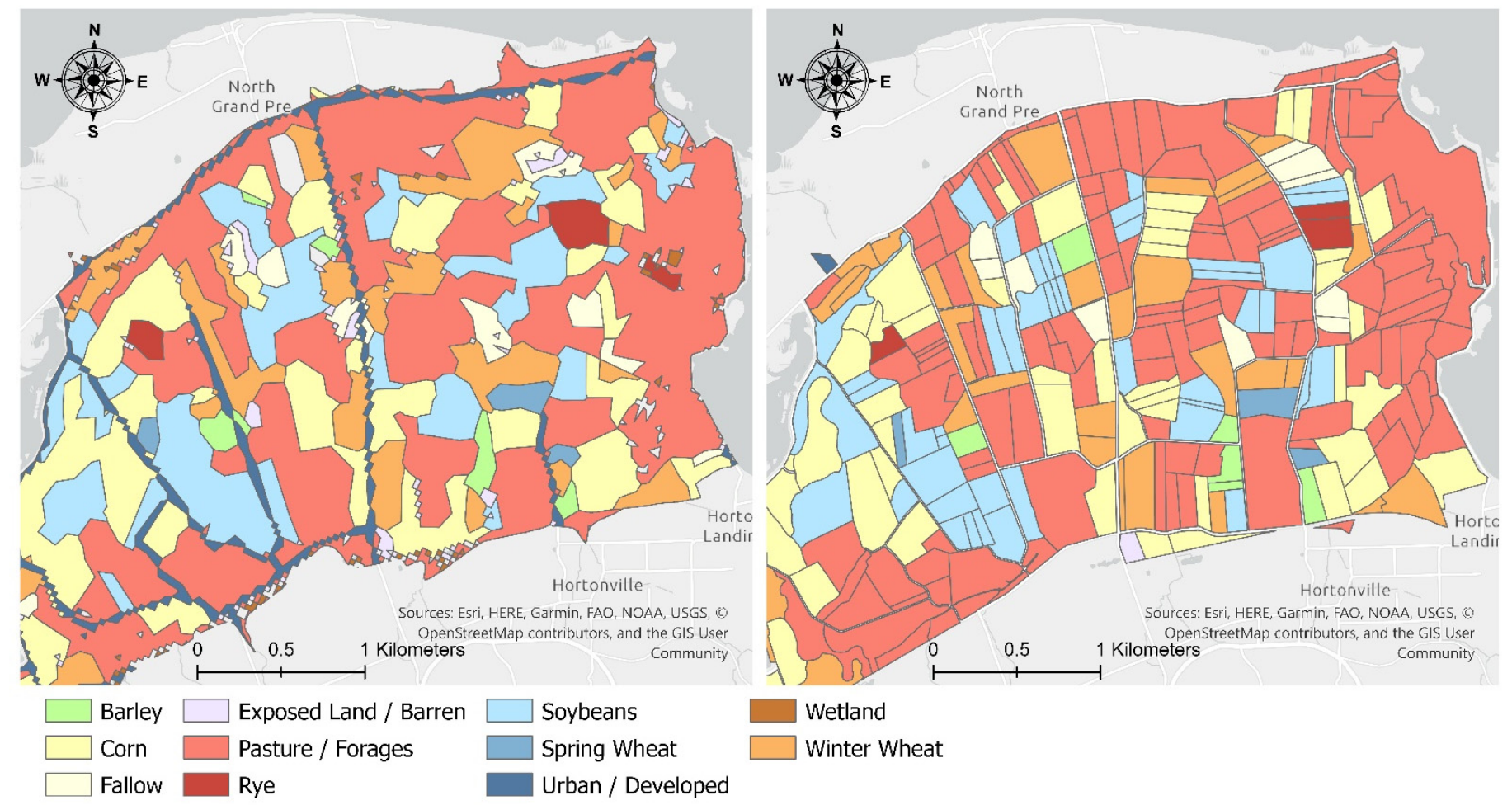

Figure 3. Examples of the Annual Crop Inventory in Grand-Pré, Nova Scotia (left) and assigned to property boundary from the NSPRD (right).

\subsection{Extraction of Crops and Data Filtering}

The property boundaries containing the crop inventory information generated in the previous steps were sequentially selected and extracted to a new dataset. Here, crops were manually filtered using information from the assessment value classification code taken from the NSPRD (Table 3). All the fields with a class other than resource taxable, resource farm, federal farm, provincial farm and municipal farm were removed from the analysis. The filtering process was especially helpful in removing the forage classes, which were not used for agriculture purposes but listed in the Annual Crop Inventory. This situation was prevalent for the residential houses with large open grass fields that are not used for agriculture. 
Table 3. Assessment Value Classification Code taken from the Nova Scotia Property Records Database (adapted from Province of Nova Scotia [31]).

\begin{tabular}{cc}
\hline Code & Feature Explanation \\
\hline 1 & Residential taxable \\
2 & Commercial taxable \\
3 & Resource taxable \\
21 & Residential exempt \\
22 & Commercial exempt \\
23 & Resource exempt \\
24 & Nonprofit land \\
25 & Resource farm \\
26 & Commercial forest \\
27 & Resource forest \\
50 & Federal farm \\
51 & Provincial farm \\
52 & Municipal farm \\
54 & Federal forest \\
55 & Provincial forest \\
56 & Municipal forest \\
\hline
\end{tabular}

The area of each polygon was calculated using the calculate geometry tool within ArcGIS pro. The resulting values were used to calculate the hectares of crops grown within each polygon, assuming that the entire polygon was cultivated. To eliminate possible errors caused by this assumption, field boundaries were visually assessed from time-series satellite imagery from PlanetScope and outliers were subsequently removed from the analysis. Similar techniques of visual assessment are described in North et al. [22] and Rahman et al. [32]. Satellite images were also used to reduce ambiguity during the process of identifying the agricultural fields. Agricultural dykelands can be identified from highresolution satellite images by locating series of open ditches parallel to each other that are typically spaced 45 to $60 \mathrm{~m}$ apart [33]. All these steps were carried out on data from the Annual Crop Inventory for 2015 to 2019.

\section{Results}

\subsection{Analysis of the Agriculture and Agri-Food Canada Crop Inventory}

Results from the Annual Crop Inventory dykelands analysis were compiled in Table 4. These results show dykeland utilization before filtering using information from the assessment value classification code. The analysis of the Annual Crop Inventory revealed that out of the total 16,238 hectares of provincial dykelands, $60 \%$ of the land area was dedicated to the production of field crops and forage. Interestingly, the production of vegetables, small fruits and potatoes has remained negligeable in comparison to other crops. An average of approximately 11,735 hectares of dykelands were labelled as forage or pasture fields in the last five years. 
Table 4. Analysis of the Agriculture and Agri-Food Canada's Annual Crop Inventory from 2015 to 2019.

\begin{tabular}{ccccccc}
\hline Crops & $\mathbf{2 0 1 5}$ & $\mathbf{2 0 1 6}$ & $\mathbf{2 0 1 7}$ & $\mathbf{2 0 1 8}$ & $\mathbf{2 0 1 9}$ & Average \\
\hline Barley & 52 & 68 & 11 & 42 & 149 & 64 \\
Beans & - & - & - & - & 9 & 9 \\
Blueberry & 67 & 13 & - & 2 & 6 & 22 \\
Broadleaf & 39 & 82 & 174 & 116 & 44 & 91 \\
Coniferous & 52 & 57 & 82 & 79 & 72 & 68 \\
Corn & 1123 & 1353 & 1311 & 1330 & 1125 & 1249 \\
Exposed Land/Barren & 7 & 40 & 250 & 259 & 119 & 135 \\
Fallow & 68 & 2 & 55 & 16 & 155 & 59 \\
Grassland & 8 & 19 & 6 & 189 & 20 & 49 \\
Mixedwood & 24 & 40 & 6 & 4 & 5 & 16 \\
Nursery & - & - & - & - & 12 & 12 \\
Oats & 35 & 13 & 20 & 64 & 2 & 27 \\
Orchards & 18 & 17 & 23 & 28 & 4 & 18 \\
Other Vegetables & 22 & 30 & 45 & 9 & 29 & 27 \\
Pasture/Forages & 11,790 & 11,838 & 11,720 & 11,028 & 11,925 & 11,660 \\
Potatoes & 99 & 148 & 33 & - & 11 & 73 \\
Rye & - & - & - & 104 & 10 & 57 \\
Shrubland & 765 & 97 & 202 & 300 & 118 & 297 \\
Sod & 12 & 10 & - & 13 & 4 & 10 \\
Soybeans & 386 & 468 & 494 & 351 & 580 & 456 \\
Spring Wheat & - & - & 5 & 34 & 60 & 33 \\
Urban / Developed & 527 & 456 & 359 & 518 & 234 & 419 \\
Water & 64 & 57 & 50 & 55 & 50 & 55 \\
Wetland & 377 & 720 & 772 & 928 & 868 & 733 \\
Winter Wheat & 270 & 212 & 162 & 301 & 170 & 223 \\
Roads / Railways & 463 & 463 & 463 & 463 & 463 & 463 \\
\hline Total (hectares) & 16,270 & 16,204 & 16,244 & 16,234 & 16,244 & 16,239 \\
\hline & & & & & &
\end{tabular}

\subsection{Average Area of Crop Production from 2015 to 2019}

From 2015 to 2019, an average of 9880 hectares of field crops (wheat, barley, corn, soybeans) and forage were cultivated on Nova Scotia's dykelands (Table 5). Over the last five years, the production of barley has been limited in comparison to the other crops, making up $0.65 \%$ of the area of crops grown.

Table 5. Five year averages of crops produced on the dykelands of Nova Scotia.

\begin{tabular}{cc}
\hline Crops & 2015-2019 Averages (Hectares) \\
\hline Wheat * & 242 \\
Barley & 64 \\
Corn & 1247 \\
Forages & 7870 \\
Soybeans & 456 \\
\hline Total (hectares) & 9880 \\
\hline
\end{tabular}

* Average of Spring and Winter wheat.

On a 5-year average, corn was the second-most abundant crop, with 1247 hectares grown annually, followed by soybeans and wheat with 456 hectares and 242 hectares grown, respectively. This number varied marginally from year to year, ranging from 9395 hectares in 2018 to 10,251 hectares in 2016 (Table 6). 
Table 6. Hectares of crops produced within the marsh bodies of Nova Scotia.

\begin{tabular}{cccccc}
\hline Crops & $\mathbf{2 0 1 5}$ & $\mathbf{2 0 1 6}$ & $\mathbf{2 0 1 7}$ & $\mathbf{2 0 1 8}$ & $\mathbf{2 0 1 9}$ \\
\hline Wheat * & 270 & 212 & 0 & - & - \\
Spring wheat & - & - & 5 & 34 & 60 \\
Winter wheat & - & - & 162 & 301 & 168 \\
Barley & 52 & 68 & 11 & 42 & 149 \\
Corn & 1119 & 1353 & 1311 & 1330 & 1125 \\
Forages & 7908 & 8150 & 7946 & 7336 & 8011 \\
Soybeans & 386 & 468 & 494 & 351 & 580 \\
\hline Total (hectares) & 9736 & 10,251 & 9929 & 9395 & 10,093
\end{tabular}

* This sub-cereal class is mapped only if the distinction of sub-wheat covers Spring Wheat or Winter Wheat is not possible.

\subsection{Area of Crop Production by County}

Over a period of five years, the dykelands from the Hants and Kings Counties produced the most field crops and forage of all the other counties in the province (Table 7). Almost $75 \%$ of the province's croplands dedicated to the production of corn were in this county. Similarly, the production of soybeans and wheat was disproportionally high in the Hants and Kings Counties, ranging from 81 to 91\%. Dykeland fields in Cumberland County were mainly used to produce forage, which represented almost $25 \%$ of the province's dykeland area.

Table 7. Hectares of field crops and forage produced by counties.

\begin{tabular}{|c|c|c|c|c|c|c|c|c|c|c|}
\hline & & \multicolumn{2}{|c|}{ Kings \& Hants } & \multicolumn{2}{|c|}{ Colchester } & \multicolumn{2}{|c|}{ Cumberland } & \multicolumn{2}{|c|}{ Annapolis } & \multirow[b]{2}{*}{ Total Hectares } \\
\hline & & Hectares & $\%$ & Hectares & $\%$ & Hectares & $\%$ & Hectares & $\%$ & \\
\hline \multirow{7}{*}{2015} & Wheat* & 236 & 87 & 13 & 4 & 0 & 0 & 22 & 7 & 270 \\
\hline & Spring wheat & - & - & - & - & - & - & - & - & - \\
\hline & Winter wheat & - & - & - & - & - & - & - & - & - \\
\hline & Barley & 0 & 0 & 13 & 26 & 34 & 54 & 5 & 6 & 52 \\
\hline & Corn & 847 & 76 & 140 & 12 & 0 & 0 & 132 & 11 & 1119 \\
\hline & Forages & 2770 & 35 & 1662 & 21 & 2000 & 25 & 1477 & 19 & 7908 \\
\hline & Soybeans & 314 & 81 & 65 & 15 & 6 & 1 & 2 & 0 & 386 \\
\hline \multirow{7}{*}{2016} & Wheat * & 212 & 100 & 0 & 0 & 0 & 0 & 0 & 0 & 212 \\
\hline & Spring wheat & - & - & - & - & - & - & - & - & - \\
\hline & Winter wheat & - & - & - & - & - & - & - & - & - \\
\hline & Barley & 25 & 37 & 26 & 31 & 7 & 7 & 10 & 10 & 68 \\
\hline & Corn & 952 & 70 & 194 & 14 & 0 & 0 & 207 & 15 & 1353 \\
\hline & Forages & 2699 & 33 & 1578 & 19 & 2317 & 28 & 1555 & 19 & 8150 \\
\hline & Soybeans & 378 & 81 & 75 & 15 & 0 & 0 & 15 & 3 & 468 \\
\hline \multirow{7}{*}{2017} & Wheat * & - & - & - & - & - & - & - & - & - \\
\hline & Spring wheat & 0 & 0 & 5 & 100 & 0 & 0 & 0 & 0 & 5 \\
\hline & Winter wheat & 162 & 100 & 0 & 0 & 0 & 0 & 0 & 0 & 162 \\
\hline & Barley & 11 & 100 & 0 & 0 & 0 & 0 & 0 & 0 & 11 \\
\hline & Corn & 979 & 75 & 248 & 19 & 0 & 0 & 83 & 6 & 1311 \\
\hline & Forages & 2544 & 32 & 1538 & 19 & 2232 & 28 & 1631 & 20 & 7946 \\
\hline & Soybeans & 428 & 87 & 38 & 7 & 24 & 4 & 4 & 1 & 494 \\
\hline \multirow{7}{*}{2018} & Wheat * & - & - & - & - & - & - & - & - & - \\
\hline & Spring wheat & 34 & 100 & 0 & 0 & 0 & 0 & 0 & 0 & 34 \\
\hline & Winter wheat & 274 & 91 & 0 & 0 & 0 & 0 & 28 & 8 & 301 \\
\hline & Barley & 32 & 77 & 10 & 13 & 0 & 0 & 0 & 0 & 42 \\
\hline & Corn & 971 & 73 & 189 & 14 & 0 & 0 & 171 & 13 & 1330 \\
\hline & Forages & 2457 & 33 & 1393 & 19 & 1967 & 27 & 1520 & 21 & 7336 \\
\hline & Soybeans & 321 & 91 & 30 & 8 & 0 & 0 & 0 & 0 & 351 \\
\hline \multirow{7}{*}{2019} & Wheat * & - & - & - & - & - & - & - & - & - \\
\hline & Spring wheat & 11 & 19 & 10 & 16 & 23 & 39 & 15 & 26 & 60 \\
\hline & Winter wheat & 168 & 100 & 0 & 0 & 0 & 0 & 0 & 0 & 168 \\
\hline & Barley & 41 & 27 & 5 & 3 & 104 & 69 & 0 & 0 & 149 \\
\hline & Corn & 754 & 67 & 250 & 22 & 0 & 0 & 121 & 11 & 1125 \\
\hline & Forages & 2594 & 32 & 1552 & 19 & 2207 & 28 & 1658 & 21 & 8011 \\
\hline & Soybeans & 515 & 89 & 65 & 11 & 0 & 0 & 0 & 0 & 580 \\
\hline
\end{tabular}

* This sub-cereal class is mapped only if the distinction of sub-wheat covers Spring Wheat or Winter Wheat is not possible. 


\section{Discussion}

The in-depth analysis of the Annual Crop Inventory revealed that roughly one-third of the approximately 11,735 hectares of forage inventoried on the dykelands were classified in the NSPRD as non-agricultural fields. This represents approximately 3844 hectares of forage fields that were not utilized for agricultural production. Although this represents a large area, two factors can explain the main causes of this discrepancy.

First, the zonal statistics tool used to calculate the dominant class within each polygon tended to categorize residential and commercial property fields as forages. Large areas of lawn grass in rural areas often resulted in these areas being categorized as forage fields. However, this issue was corrected by filtering out these fields using property records from the NSPRD and satellite images. Additionally, the overall accuracy of the Annual Crop Inventory model used to generate the inventory for non-agricultural land cover was approximately $70 \%$, yearly [29]. The presence of large lawn areas and a reduced accuracy for non-agricultural cover could mean that this analysis underestimated the number of hectares of fields used for residential and commercial applications, thus overestimating the total forage hectares.

The second factor that may explain the discrepancies between the number of hectares of forages from the Annual Crop Inventory and the calculated values could be that some forage fields were isolated, inaccessible to farmers, or owned by provincial and federal agencies who are not farming these fields. For example, the Minudie dyke system $\left(45.8086^{\circ} \mathrm{N}\right.$, $64.3229^{\circ} \mathrm{W}$ ) represented 1422 hectares of forage dykeland that was not utilized for farming [34]. This large land area was removed from the analysis since it was not currently used for agricultural production.

\subsection{Fields Crops and Forages on the Dykelands}

Historically, there was no significant difference in which crops could be successfully produced on the uplands versus the dykelands [35]. The problem with high value cash crops was not so much that dykelands could not support the crops but resides in the inherent difficulty associated with drainage [36]. Dykelands soils have low permeability and poor surface drainage, thus requiring land forming to maximize their potential [37]. Over time, however, plowing causes soil redistribution and thereby modifies the topography; hence, dykeland fields must be reformed - a process known as "recrowning".

In Nova Scotia, field drainage is often the limiting factor on the types of crops that may be successfully grown (Figure 4) [33]. Gartley et al. noted that it is generally difficult to grow valuable cash crop on recently drained land [33]. It is advised to grow grain or hay crop for several years following an initial re-crowning to help improve the soil structure. This management practice will in turn, improve soil drainage and aeration over time, as the crop rooting zone extends deeper into the soil profile [33].

High value cash crops often require more intensive machinery use, which may increase the risk of soil compaction [33]. Intensive farming of row crops may then lead to the degradation of soil structure, which will negatively impact the mobility of water and reduce the effectiveness of the drainage [38]. This creates a cycle that is difficult to recover from without a complete recrowning of the field. On poorly drained dykelands, farmers are often cautious to seed field crops since they are concerned that they will not be able to harvest their fields in the fall [34]. This could explain the prevalence of forage and pasture on the dykelands, relative to other crops. Forages makes up the largest commodity grown, representing around $80 \%$ of the total agricultural dykelands. This production is even more essential considering that dykelands are usually more productive than the uplands [39].

Langille and Warren demonstrated in their study that over a 3-year period, forage yields on dykelands were $20 \%$ greater as compared to upland crops. Furthermore, they noticed that seasonal distribution of forage was better on the dykelands than the uplands, which allows them to excel in the production of timothy (Phleum pratense), orchard grass (Dactylis glomerata L.), red clover (Trifolium pratense L.), alfalfa (Medicago sativa L.) or Ladino clover forages (Trifolium repens L.) [39]. 


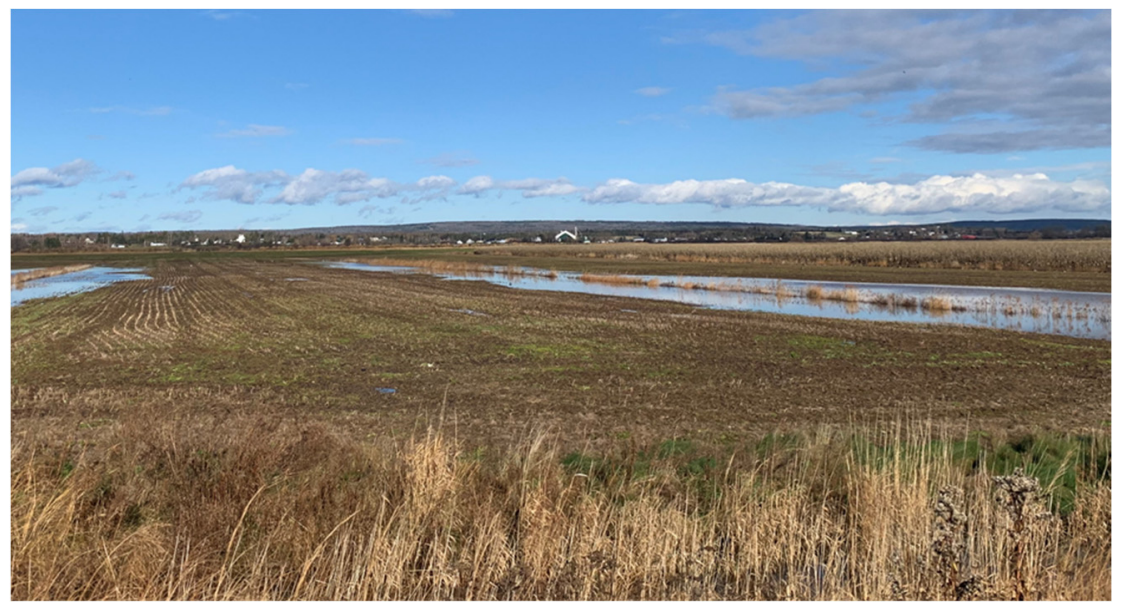

Figure 4. Dykeland field in Truro, Nova Scotia $\left(45.3729^{\circ} \mathrm{N}, 63.2954^{\circ} \mathrm{W}\right)$ with water-saturated areas. Image was captured on the morning of 11 November 2020.

Information from the federal census of agriculture also revealed that forage production in Nova Scotia represented $60 \%$ of the total agricultural land in the province $[27,40]$. It is important to note that $80 \%$ of the agricultural dykeland fields in the province are used to grow forage, which far surpasses forage production on provincial upland fields.

\subsection{Limitations}

The strength of this methodology depends mainly on the quality of both the AAFC's Annual Crop Inventory and the NSPRD. The NS property boundaries can either overor underestimate the hectares of land cultivated. A more in-depth segmentation of the field boundaries, followed by field surveys, could increase the overall accuracy of the estimations. Additionally, if not up to date, the property boundaries database could lead to discrepancies between estimation of lands cultivated and reality. For instance, if the land use of a property boundary has changed from agricultural production to residential and the information has not been updated to the database, this could misrepresent the results. This type of discrepancy can be minimized by using the latest dataset available and, if possible, by ground proofing the results to reduce ambiguity.

Another limitation of this analysis lies in the fact that it only contained the results from the last five years. Unfortunately, the 2020 AAFC Annual Crop Inventory could not be completed in Nova Scotia due to COVID-19 travel restrictions. These restrictions prevented the collection of ground data collected, making it impossible to define an agricultural class precisely [29]. An in-depth analysis over a more extended period would provide a detailed representation of the agricultural situation on the dykelands. Finally, the technique presented in this analysis requires users to have a fair understanding of GIS software, thus requiring qualified GIS professionals to conduct the analysis.

\section{Conclusions}

To make more informed land management decisions on dykelands, a detailed inventory of corn, barley, soybeans, wheat, and forages was compiled. This paper aimed to increase the understanding of the land allocation of field crops and forages on the dykelands of Nova Scotia by estimating the total number of hectares of cropland produced from 2015 to 2019. Evidence from previous report on agricultural dykelands by Baird [3], Milligan [4] and Singh et al. [9] demonstrated a vague understanding of the state of agricultural situation on the dykelands. This research is particularly important in today's context, where challenging decisions will have to be made in the upcoming years when considering the future of the Nova Scotia dyke system, thus affecting agricultural dykelands. If it is not cost-effective to maintain dykelands, it may be necessary to compensate landowners with upland lots. Knowing when and how to manage these scenarios requires more study on the 
long-term economic value of agricultural dykelands, which requires a deep understanding of the cropping potentials. To date, there has been no comprehensive crop inventory of the dykelands. Understanding cropping potential on the dykelands will help prepare for long-term food security for the region, which is essential given the possible impacts of climate change. This study provides quantifiable information on the land usage of the dykelands, thus helping government agencies to make informed decisions regarding agricultural protection on the dykelands. Furthermore, the work presented in this paper lays the framework for how this method can be duplicated for future years. This would allow the possibility to evaluate changes in production and the number of acres farmed over time. In addition, this work could be beneficial to local authorities for decision making. The model presented in this analysis could also be expanded to other regions of Canada. For example, the province of New Brunswick, Canada, is currently facing similar issues to Nova Scotia and is protecting almost 15,000 hectares of dykelands in which $41 \%$ are not being farmed. This analysis could improve decision making by increasing the knowledge on crops cultivated [9].

This analysis provides a more precise representation of the agricultural utilization of the dykelands. To date, this work represents the first robust crop inventory of the major crops grown on the dykelands. Results from the five-year averages of this analysis revealed two significant trends. First, more than half of the Nova Scotian dykelands are being used for agricultural production. Second, the production of forage is predominant on the agricultural dykelands constituting approximately $80 \%$ of the total crop land area. This finding is important considering that the second (corn) and third (soybeans) crops of abundance only represent 12 and $4 \%$ of the total crop land area, respectively.

Further research will be conducted to improve the field boundaries segmentation and provide recommendations for future cultivation based on the information gathered in this analysis. This will be accomplished by refining the resolution of the crop inventory by using higher-resolution satellite images (e.g., Sentinel 2) and conducting field interviews with dykelands farmers to understand the economics of dykelands farming.

Author Contributions: Conceptualization, Mathieu F. Bilodeau and Travis J. Esau; methodology, Mathieu F. Bilodeau, Travis J. Esau and Brandon Heung; software, Mathieu F. Bilodeau; validation, Mathieu F. Bilodeau, Travis J. Esau and Brandon Heung; formal analysis, Mathieu F. Bilodeau; investigation, Mathieu F. Bilodeau; resources, Travis J. Esau, Aitazaz A. Farooque and Qamar U. Zaman; data curation, Mathieu F. Bilodeau; writing—original draft preparation, Mathieu F. Bilodeau; writing - review and editing, Mathieu F. Bilodeau, Travis J. Esau and Brandon Heung; visualization, Mathieu F. Bilodeau and Travis J. Esau; supervision, Travis J. Esau, Aitazaz A. Farooque, Qamar U. Zaman and Brandon Heung; project administration, Travis J. Esau and Mathieu F. Bilodeau; funding acquisition, Travis J. Esau, Aitazaz A. Farooque and Qamar U. Zaman. All authors have read and agreed to the published version of the manuscript.

Funding: This research was financially supported by the following grant sources: Atlantic Land Improvement Contractors' Association (ALICA), Mitacs Accelerate, Natural Sciences and Engineering Research Council of Canada (NSERC) Discovery Grants Program (RGPIN-06295-2019).

Institutional Review Board Statement: Not applicable.

Informed Consent Statement: Not applicable.

Data Availability Statement: The data presented in this study are available on request from the corresponding author.

Acknowledgments: The authors would like to thank ALICA, Mitacs and NSERC for financial support to complete this work. The authors would also like to give thanks to the mechanized systems research team at Dalhousie's Faculty of Agriculture.

Conflicts of Interest: The authors declare no conflict of interest. 


\section{References}

1. Nova Scotia Department of Lands and Forestry. Fundy Dykelands and Wildlife-A Short History. Available online: https: // novascotia.ca/natr/wildlife/habitats/dykelands/ (accessed on 8 July 2020).

2. Asiedu, G. Citizens' Perception of Values Associated with Dykes and Dykelands: The Case of Nova Scotia. MSc., Dalhousie University. Available online: https:/ / dalspace.library.dal.ca/xmlui/bitstream/handle/10222/21745/Asiedu-Grace-MES-ENVIDecember-2012.pdf?sequence=3\&isAllowed $=y$ (accessed on 12 June 2021).

3. Baird, W.W. Report on Dykeland Reclamation, 1913 to 1952; Ottawa: Queen's Printer: Nappan, NS, Canada, 1954.

4. Milligan, D.C. Maritime Dykelands: The 350 Year Struggle.; Province of Nova Scotia, Department of Agriculture and Marketing: Halifax, NS, Canada, 1987.

5. Devanney, M.; Reinhardt, F. An Overview of the Nova Scotia Agriculture and Agri-Food Industry. 2010. Available online: https:// novascotia.ca/agri/documents/business-research/AO0102\%202010\%20NS\%20Ag\%20Overview\%20w\%20Appendices.pdf (accessed on 17 May 2021).

6. Gorman, M. \$114M Announced to Help N.S. Prepare for Rising Sea Levels, Storms. CBC. 2019. Available online: https://www. cbc.ca/news/canada/nova-scotia/coastal-flooding-sea-rise-aboiteau-dikes-federal-provincial-funding-1.5101470 (accessed on 15 June 2021).

7. Sherren, K.; Loik, L.; Debner, J.A. Climate Adaptation in 'New World' Cultural Landscapes: The Case of Bay of Fundy Agricultural Dykelands (NS, Canada). Land Use Policy 2016, 51, 267-280. [CrossRef]

8. Jones, C. Business Planning and Economics of Forage Establishment and Cost of Production in Nova Scotia N.A. Available online: https://www.sciencedirect.com/science/article/abs/pii/S0264837715003749 (accessed on 8 May 2021).

9. Singh, K.; Walters, B.; Ollerhead, J. Climate Change, Sea-Level Rise and the Case for Salt Marsh Restoration in the Bay of Fundy, Canada. Environments 2007, 35, 71-84.

10. Philp, G.; Cohen, A. Municipal Climate Change Adaptation and Mitigation: From Planning to Action in Nova Scotia. J. Environ. Plan. Manag. 2020, 63, 1927-1945. [CrossRef]

11. Webster, T.; Kongwongthai, M.; Crowell, N. An Evaluation of Flood Risk to Infrastructure across the Chignecto Isthmus; Scotia Department of Transportation and Infrastructure Renewal: Halifax, NS, Canada, 2012; p. 45.

12. Drever, C.R.; Cook-Patton, S.C.; Akhter, F.; Badiou, P.H.; Chmura, G.L.; Davidson, S.J.; Desjardins, R.L.; Dyk, A.; Fargione, J.E.; Fellows, M.; et al. Natural Climate Solutions for Canada. Sci. Adv. 2021, 7, eabd6034. [CrossRef] [PubMed]

13. Van Proosdij, D.; Page, S. Best Management Practices for Climate Change Adaptation in Dykelands: Recommendations for Fundy ACAS Sites; Saint Mary's University: Halifax, NS, Canada, 2012; p. 149.

14. Van Proosdij, D.; Ross, C.; Matheson, G. Risk Proofing Nova Scotia Agriculture: Nova Scotia Dyke Vulnerability Assessment; Saint Mary's University: Halifax, NS, Canada, 2018; p. 51.

15. Loveland, T.R.; Reed, B.C.; Brown, J.F.; Ohlen, D.O.; Zhu, Z.; Yang, L.; Merchant, J.W. Development of a Global Land Cover Characteristics Database and IGBP DISCover from $1 \mathrm{Km}$ AVHRR Data. Int. J. Remote Sens. 2000, 21, 1303-1330. [CrossRef]

16. Loveland, T.R.; Merchant, J.W.; Ohlen, D.O.; Brown, J.F. Development of a Land-Cover Characteristics Database for the Conterminous US. Photogramm. Eng. Remote Sens. 1991, 57, 1453-1463.

17. Skole, D.; Tucker, C. Tropical Deforestation and Habitat Fragmentation in the Amazon: Satellite Data from 1978 to 1988. Science 1993, 260, 1905-1910. [CrossRef] [PubMed]

18. Sleeter, B.M.; Sohl, T.L.; Loveland, T.R.; Auch, R.F.; Acevedo, W.; Drummond, M.A.; Sayler, K.L.; Stehman, S.V. Land-Cover Change in the Conterminous United States from 1973 to 2000. Glob. Environ. Chang. 2013, 23, 733-748. [CrossRef]

19. Matthews, E. Global Vegetation and Land Use: New High-Resolution Data Bases for Climate Studies. J. Clim. Appl. Meteorol. 1983, 22, 474-487. [CrossRef]

20. Olson, J.S.; Watts, J.A.; Allison, L.J. Major World Ecosystem Complexes Ranked by Carbon in Live Vegetation: A Database. Available online: https:/ / cdiac.ess-dive.lbl.gov / epubs/ndp/ndp017/ndp017_1985.html (accessed on 2 July 2021).

21. Wilson, M.F.; Henderson-Sellers, A. A Global Archive of Land Cover and Soils Data for Use in General Circulation Climate Models. J. Climatol. 1985, 5, 119-143. [CrossRef]

22. North, H.C.; Pairman, D.; Belliss, S.E. Boundary Delineation of Agricultural Fields in Multitemporal Satellite Imagery. IEEE J. Sel. Top. Appl. Earth Obs. Remote Sens. 2019, 12, 237-251. [CrossRef]

23. McCracken, S.D.; Brondizio, E.S.; Nelson, D.; Moran, E.F.; Siqueira, A.D.; Rodriguez-Pedraza, C. Remote Sensing and GIS at Farm Property Level: Demography and Deforestation in the Brazilian Amazon. Photogramm. Eng. Remote Sens. 1999, 65, $1311-1320$.

24. Hanus, P.; Pęska-Siwik, A.; Szewczyk, R. Spatial Analysis of the Accuracy of the Cadastral Parcel Boundaries. Comput. Electron. Agric. 2018, 144, 9-15. [CrossRef]

25. Meyer, L.; Lemarchand, F.; Sidiropoulos, P. A Deep Learning Architecture for Batch-Mode Fully Automated Field Boundary Detection. Int. Arch. Photogramm. Remote Sens. Spat. Inf. Sci. ISPRS Arch. 2020, 43, 1009-1016. [CrossRef]

26. Fisette, T.; Davidson, A.; Daneshfar, B.; Rollin, P.; Aly, Z.; Campbell, L. Annual Space-Based Crop Inventory for Canada: 2009-2014. In Proceedings of the 2014 IEEE Geoscience and Remote Sensing Symposium, Quebec City, QC, Canada, 13-18 July 2014; pp. 5095-5098.

27. Government of Canada. 2011 Census of Agriculture. Available online: https://www.statcan.gc.ca/eng/ca2011/index (accessed on 2 July 2021). 
28. Sherren, K.; Bowron, T.; Graham, J.; Rahman, H.M.; Proosdij, D. Coastal Infrastructure Realignment and Salt Marsh Restoration in NS, Canada; Responding to Rising Seas: OECD Country Approaches to Tackling Coastal Risks; OECD Publishing: Paris, France, 2019.

29. Agriculture and Agri-Food Canada. Annual SpaceBased Crop Inventory for Canada. Available online: https://open.canada.ca/ data/en/dataset/d90a56e8-de27-4354-b8ee-33e08546b4fc (accessed on 24 March 2021).

30. Planet Labs. Planet Imagery Product Specification. Available online: https://planet.com/products/planet-imagery/ (accessed on 10 May 2021).

31. Province of Nova Scotia. Nova Scotia Property Records Database-Reference File 2019. Available online: https://novascotia.ca/ sns/access/land/property-online.asp (accessed on 23 May 2021).

32. Rahman, M.S.; Di, L.; Yu, Z.; Yu, E.G.; Tang, J.; Lin, L.; Zhang, C.; Gaigalas, J. Crop Field Boundary Delineation Using Historical Crop Rotation Pattern. In Proceedings of the 2019 8th International Conference on Agro-Geoinformatics (Agro-Geoinformatics), Istanbul, Turkey, 16-19 July 2019; pp. 1-5.

33. Gartley, C.; Cochrane, L.; DeHaan, R.; Madani, A. Farm Drainage in the Atlantic Provinces. 1986. Available online: https: //www.nsefp.ca/wp-content/uploads/2018/08/Farm-Drainage-in-the-Atlantic-Provinces-cover-revised.pdf (accessed on 11 June 2021).

34. Esau, C. Minudie Dykeland System. Personal communication, 2021.

35. Bleakney, J.S. Sods, Soil, and Spades: The Acadians at Grand Pre and Their Dykeland Legacy; McGill-Queen's University Press: Montreal, QC, Canada, 2004; ISBN 978-0-7735-2816-1.

36. Juurlink, N. Cost Associated with Farming the Dykeland. Personal communication, 2021.

37. Kolstee, H.; Collette, L.; Cochrane, L. Dykeland Land Forming. In Proceedings of the Atlantic Committee on Agricultural Engineering, Fredericton, NB, Canada, 22-24 February 1994; Volume 29, p. 2.

38. Soil Conservation Service. Drainage of Agricultural Land; Water Information Center: Port Washington, NY, USA, 1973.

39. Langille, J.E.; Warren, F.S. Response of Certain Forage Species on Dikeland and Upland to Various Clipping Intensities. Can. J. Plant Sci. 2011, 41, 693-702. [CrossRef]

40. Government of Canada. 2016 Census of Agriculture. Available online: https:/ /www.statcan.gc.ca/eng/ca2016 (accessed on 2 July 2021). 